\title{
ARCHAEOLOGY OF KESH AND SHAKHRISABZ: ON THE BASIS OF KATE REPORTS
}

\author{
Zukhriddin Khaydarov
}

Lecturer National university of Uzbekistan Tashkent, Uzbekistan

\section{ABSTRACT}

This article discusses archaeology of Kesh and Shakhrisabz: on the basis of KATE reports. Shakhrisabz is an ancient oasis due to very favorable natural and geographical conditions. Surrounded by the Gissar and Zarafshan mountain ranges, the region has a temperate climate, where many tributaries of the Kashkadarya have long been able to supply the necessary water resources. This oasis formed the territory of South Sogd, and its inhabitants had their own ancient culture.

\section{KEYWORDS: - Archaeological study, Shakhrisabz, KATE, Gissar.}

\section{INTRODUCTION}

Archaeological study of the material culture of Shakhrisabz began in 20th centuries by the Institute of History and Archaeology of the Academy of Sciences of the Republic of Uzbekistan and the Department of Archaeology of Tashkent State University (National University of Uzbekistan).

Z. Usmanova studied walls of the medieval castle of Shakhrisabz in

1963-1965, the historical topography of the city of Amir Temur and the Temurids. The materials of the excavations of the ancient city on the Kitab territory were also studied. In 1965-1966, the Kesh archaeological and topographic expedition (KATE) under the leadership of M.E. Masson carried out observational studies in the Karshi oasis [1].

\section{THE MAIN RESULTS AND FINDINGS}

The issue of organizing a special expedition to the Kashkadarya region, including to Kesh, in the early 1960 s was a special task of the Department of Archaeology of Tashkent State University. Associate professor of the department Z.I. Usmanova: "The question of organizing an independent archaeological expedition at the department stood at a crossroads. In this case, the less studied archaeologically Kashkadarya region was chosen. This region was the southern part of ancient Sogd (Kesh-Nasaf) and is mentioned in written sources [2].

In 1963, at the Department of Archaeology of Tashkent State University under the leadership of Professor M.E. Masson organized the Kesh archaeological and topographic expedition (KATE).

The Kesh archaeological and topographic 
CURRENT RESEARCH JOURNAL OF HISTORY 2(11): 52-57, November

2021

DOI: https://doi.org/10.37547/history-crjh-02-11-11

ISSN 2767-472X

(C2021 Master Journals

Crossref do:

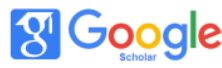

Accepted 25th November, 2021 \& Published 30th November, 2021

expedition (KATE), when exploring the Kashkadarya oasis, works in two main directions.

1. Drawing up the historical topography of cities and villages;

2. Development of an archaeological map of the eastern regions of the Kashkadarya region.

Archaeologists and art historians are diligently studying the artifacts of the southern oasis that have not yet been discovered. Researchers such as

N.I. Krasheninnikova [3], S.B. Lunina [4], N.P. Stolyarova [5], R.R. Abdurasulov,

L.I. Rempel [6], brought significant innovations to science about the ancient culture of the Kesh oasis.

In 1966, archaeological research began on the Oltintepa monument, a large medieval city center in the Kamashi region [7]. In 1967, on the southeastern shore of the Chimkurgan reservoir (Kamashi district) Z. Usmanova He found pottery from the 5th-3rd centuries BC. An additional inspection in 1972 showed that the item had been washed away from the decomposing layers of Nomsiztepa-9 [8].

In the early 70s of the last century, KATE began a large-scale planned survey of five districts of the Kashkadarya region in order to create a list of monuments and an archaeological map. Research began in the Kamashi region in 1972, and along with the studied archaeological monuments of Antik, Saritepa 1,2 explores the settlements of the last Antik and the early Middle Ages.

As a result of research carried out by A.S. Sagdullaev at the Department of Central Asian Archaeology of the Tashkent State University in 1976-1979, in the eastern part of the Kashkadarya oasis, a number of monuments of the early Iron Age were discovered [9].

As a result of many years of research on the monuments of Daratepa, Structures of various dwellings of the 7 th- 4 th centuries $\mathrm{BC}$ have been excavated.

In 1981-1984, an expedition led by N.I. Krasheninnikova conducted searches in the middle reaches of the Shurab River. The monuments of Podayotoktepa, Sangirtepa and Uzunkir of the first half of the first millennium were discovered and excavated.

In 1982, employees of the Kashkadarya archaeological and topographic expedition of the Department of Central Asian Archaeology of Tashkent State University conducted archaeological excavations in Shakhrisabz. During these archaeological excavations, were carried out on the northern defensive walls of Shakhrisabz, which have been preserved on the northern side of the main roof of Oksaroy. A defensive wall with a length of $10 \mathrm{~m}$ has been preserved here, and the research was carried out using the cross-sectional method, in which the eastern part of the wall was cut across it. Here the height of the wall remains $7.5 \mathrm{~m}$, and the thickness is $12 \mathrm{~m}$ along the streams of cultural layers. The section was dug to a clean soil layer. At the top of the wall there is a repaired wall made of gutters $2 \mathrm{~m}$ high. The base of the defensive wall is a wall of layered cotton fabric with a thickness of $9-20 \mathrm{~cm}$, and this wall continued the cultural layer. Under the wall - a layer of specially leveled soil $120-130 \mathrm{~cm}$ thick, which brings it to the state of a solid foundation. Under the basement there is a light-brown cultural layer with an average thickness of $1 \mathrm{~m}$, in which fragments of ceramics of the X-XII centuries were found. Beneath this cultural layer is a coating of pure land. The width of the wall along its bottom is 7 meters.

In the same 1982, archaeologists of the department carried out archaeological research in Balandtepe (Zindontepa). At the same time, 
CURRENT RESEARCH JOURNAL OF HISTORY 2(11): 52-57, November

2021

DOI: https://doi.org/10.37547/history-crjh-02-11-11

ISSN 2767-472X

(C2021 Master Journals

Crossref do:

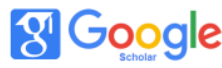

Accepted 25th November, 2021 \& Published 30 th November, 2021

the remains of a large structure were discovered and examined in the central part of Balandtepe. However, the premises discovered during archaeological excavations lack kitchen stoves and ashtrays, tools, large-capacity ceramic vessels (jugs, little jugs) for storing grain, and household items. It has not been proven that a simple house-castle associated with agriculture was built on the site of Balandtepe. However, a number of sources suggest that the large structure, built on a high and solid foundation, could have been the first medieval temple on the site of Balandtepe, as the rooms lacked household items, kitchens and farming-related items (agriculture, husbandry).

Excavations in the Yakkabag region were carried out in 1985-1986. In medieval Sariktepa. Through the city for miles a building that was a cult building of the 6th-7th centuries was investigated. S.K. Kabanov and V.D. Zhukov in the area of the Chimkurgan reservoir, S. B. Lunin and N.P. Stolyarov in the Kamashi district, G.Ya. Dresvyanskaya and D.V. Chunikhin in the Yakkabag region, N.I. Krasheninnikov. medieval Kashkadarya oasis. As a result of scientific research, the medieval religious views of the population of Eastern Kashkadarya were analyzed on the basis of architectural buildings, terracotta and other material sources [10].

In 1983 N.I. Krasheninnikova conducted research on the surviving part of the Uzunkir defensive wall. During the inspection, the remains of a tower with an entrance to it and a single pebble on the outside of the wall were unearthed. Its walls and level are plastered with straw. Fragments of pottery and bronze bow arrowheads were found on the surface.

According to research, the castle wall was built during the Achaemenid period. As a result of archaeological work carried out by A.S. Sagdullaev and
N.I. Krasheninnikova, Uzunkir was considered the center of the city of Nautaka, and later the center moved to the place of the modern city of Kitab.

In 1986, an archaeological expedition led by A.S. Sagdullaev new archaeological research was carried out in the Kashkadarya region, combining archaeological mapping with a systematic study of the historical region of Kesh and Nakhshab, one of the important results of which was the determination of Karshi (Nasaf) and Shakhrisabz (Kesh) 2,700 years old.

In the 1990s, a special study by KATE was devoted to the trade and cultural ties of the Kashkadarya oasis of the 17th-19th centuries, the study of the city of Shakhrisabz and its landscape [12].

The results of archaeological work on the monuments of the first Iron Age in the second half of the 1990s are reflected in the dissertation of 0 . N. Lushpenko. The results of an archaeological study of the monuments of Sangirtepa, Uzunkir and Daratepa made it possible to describe the order of settlement and the location of settlements, construction techniques, architectural and design features. According to the author's research, Sangirtepa and Uzungir are examples of the evolution of the first urban culture of South Sogd [13].

In the same years, the expedition of the Department of Archaeology of the National University of Uzbekistan resumed the study of the ancient monuments of the Shurabsay and Ayakchidarya oases. The dissertation of A.V. Omelchenko. In the lower reaches of Shurabsay, research was carried out on Saraitepa and Nomsiztepa, which, together with Podayotoktepa, are part of the Palvantepa settlement system. Remains of hummus, firebox and door structure were removed from residential and communal areas. The rich pottery 
CURRENT RESEARCH JOURNAL OF HISTORY 2(11): 52-57, November

2021

DOI: https://doi.org/10.37547/history-crjh-02-11-11

ISSN 2767-472X

(C2021 Master Journals

Crossref doi

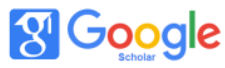

Accepted 25th November, 2021 \& Published 30th November, 2021

assemblages originated from stratigraphic layers, which made it possible to trace the evolution of pottery from the earliest stages of life in the citadel. According to Omelchenko, the fossils and excavated materials chronologically cover the period from the 2 nd century $\mathrm{BC}$ to the 2nd century AD [3].

In 1989-1992 $20 \mathrm{~km}$ from the city of Shakhrisabz. In the northwest, a complex of "nameless mausoleums" of the 14th century has been opened. The complex consisted of mausoleums and buildings of the Khanqah type that belonged to representatives of the Barlos clan, descendants of Amir Temur[6]

In 1996, on the occasion of the 660th anniversary of the birth of Amir Temur, employees of the Institute of Archaeology of the Academy of Sciences of the Republic of Uzbekistan, together with employees of the department, carried out archaeological excavations on the central square of Shakhrisabz. At the excavation site, the remains of a foundation made of baked bricks of various sizes were found. The general location of these foundations provides information on how to drive the street from here.

Since 2000, the Department of Archeology of the National University of Uzbekistan, the archaeological group of the Academy of Sciences of Uzbekistan and the University of Berkeley (USA) have been conducting joint research to create a complex of archaeological sites in Podayotoktepe using new equipment and excavations.

In 2001, together with the University of Colorado, the study of Stone Age monuments in the Eastern Kashkadarya region began. In 2001, a number of important archaeological discoveries were made. During searches along the right bank of the Kashkadarya, the caves were discovered and explored $23 \mathrm{~km}$ north-west of the city of Kitab while exploring the Oyakchisay valley. Remnants of Stone Age human life have been found in two caves. This indicates that the Kesha region was developed back in the Paleolithic period. Not far from Oyakchisay, in the neighboring Kuruksay valley, rocks with images painted in red were discovered. As noted on the previous pages, there was a rare Stone Age temple, which the present inhabitants call Sipantosh [12].

In 2006, archaeological excavations were resumed in the area, and large-scale archaeological excavations were carried out about $50 \mathrm{~m}$ east of the surviving part of the Oksaroy roof.

The discovery of a cultural layer of the 11th-12th centuries $60-70 \mathrm{~cm}$ thick and pottery from the lower layers of the pit, excavated in 2006, may serve to clarify a number of problems in the history of Kesh-Shakhrisabz.

The presence of cultural layers of the same period during the 2006 excavations, $200-250 \mathrm{~m}$ north of the excavation site in 1996, indicates that during the Karakhanid period there were large settlements that occupied a large territory.

The traditions of the ancient urban culture are reflected in the cities discovered by archaeologists in Shakhrisabz with a rich history of events, as well as in architectural monuments that have survived to this day.

\section{Conclusion}

In short, as a result of archaeological excavations carried out by archaeologists in the oasis, the region in the eastern part of Kashkadarya and its city center were located at different miles at different times. In the 9th-8th centuries BC the region was called Gava Sogda. In the 7 th- 4 th centuries BC it was called Nautaka, in the 6th15 th centuries - Kesh. It was formed in the 8th 
CURRENT RESEARCH JOURNAL OF HISTORY 2(11): 52-57, November

2021

DOI: https://doi.org/10.37547/history-crjh-02-11-11

ISSN 2767-472X

(C2021 Master Journals

\section{Crossref do) 8 Google}

Accepted 25th November, 2021 \& Published 30 th November, 2021

century BC on the site of Uzunkir and developed until the 3rd century. The history of the city in later periods was associated with the KitabShakhrisabz region. Accordingly, the 2700th anniversary of the city of Shakhrisabz was widely celebrated. In the course of a large-scale work on an archaeological map of the eastern part of Kashkadarya, the issues of zoning and classification of ancient and medieval monuments, as well as centers of early agriculture, as well as the dynamics of the development of regional culture were considered. The general features of the urbanization of Eastern Kashkadarya are highlighted. In recent years, research by scientists in the oasis has stalled for some reason. In accordance with the Resolution of the Cabinet of Ministers of the Republic of Uzbekistan dated February 20, 2014 №31 "Program of comprehensive measures for the construction and reconstruction of facilities in the city of Shakhrisabz of the Kashkadarya region"[14] in Shakhrisabz for 2015 - 2018. In these areas, it is necessary to involve the scientists of the department in field archaeological research and resume archaeological excavations.

\section{ReFERENCES}

1. Ochildiyev, F. (2019). TRADE RELATIONS BETWEEN BUKHARA AND RUSSIA IN THE SECOND HALF OF THE XIX CENTURY-THE BEGINNING OF THE XX CENTURY//Social Sciences: Achievements and Prospects Journal 3 (11), 2019/OEAPS Inc.(Open European Academy of Public Sciences); Chief Editor Mark Freeman-Barcelona, Spain. 16.03. 2019: OEAPS Inc., 2019.-pp. 55-60.

2. Ochildiyev, F. (2019). TRADE RELATIONS BETWEEN BUKHARA AND RUSSIA IN THE
SECOND HALF OF THE XIX CENTURY THE BEGINNING OF THE XX CENTURY.

3. Ochildiev, F. (2021). THE INFLOW OF RUSSIAN CAPITAL AND INDUSTRY INTO THE BUKHARA EMIRATE IN THE LATE 19TH AND EARLY 20TH CENTURIES. CURRENT RESEARCH JOURNAL OF HISTORY (2767-472X), 2(06), 20-26.

4. Очилдиев, Ф. (2021). XIX асрнинг иккинчи ярми-XX acp бошларида Сурхон вохаси бекликларининг мамурий бўлиниши ва бошқарув тизими. Общество и инновации, $2(4 / \mathrm{S})$, 387-397.

5. Ochildiev, F., \& Kuyliev, R. (2021). Location of the population and ethnic composition of surkhan oasis in the late xix and early $\mathrm{xx}$ centuries. ACADEMICIA: An International Multidisciplinary Research Journal, 11(3), 1062-1069.

6. Очилдиев, Ф. Б., \& Тогаев, Ж. Э. (2015). ЗАМЕТКИ О СИСТЕМЕ МЕСТНОГО УПРАВЛЕНИЯ В БУХАРСКОМ ЭМИРАТЕ В СЕРЕДИНЕ ХІХ-НАЧАЛЕ ХХ ВЕКА. Национальная Ассоциация Ученых, (29), 47-50.

7. Ochildiyev, F. (2019). Trade relations between Bukhara and India in the second half of the 19th century and at the beginning of the 20th century. Actual Problems of Applied Sciences Journal World, (4), 13-19.

8. Ochildiev, F. B. (2020). Social relationship and tax types in the XIX-XX century in Bukhara Emirate. International Journal of Scientific and Technology Research, 9(1), 723-729.

9. Ochildiev, F. B. (2019). The creation of the amudarya fleet. ISJ Theoretical \& Applied Science, 10(78), 583-586. 
DOI: https://doi.org/10.37547/history-crjh-02-11-11

ISSN 2767-472X

(C)2021 Master Journals

\section{Crossref do) 81 Google}

Accepted 25th November, 2021 \& Published 30 ${ }^{\text {th }}$ November, 2021

10. Muhamedov, Y. K. (2019). The history of commercial economical-cultural relations of Tashkent oasis. ISJ Theoretical \& Applied Science, 10(78), 579-582.

11. Yoqubjon Muhamedov. (2021). Chach As The Administrative Center Of The Western Khanate. International Scientific and Current Research Conferences, 1(01), 7579.

12. МУХАМЕДОВ, Ё. (2021). ЧОЧ ХУКМДОРЛИГИНИНГ СИЁСИЙМАЪМУРИЙ БОШҚАРУВИ ТАРИХШУНОСЛИГИ. In Uzbek Conference Publishing Hub (Vol. 1, No. 01, pp. 508512).

13. Dalibaevna, N. D. (2021). The Social Activity of Women Is One of the Important Factors in the Development of the Country. Eurasian Journal of Social Sciences, Philosophy and Culture.

14. Dalibaevna, N. D. (2021). GENDER EQUALITY IS ONE OF THE REQUIREMENTS OF A DEVELOPED SOCIETY. CURRENT RESEARCH JOURNAL OF HISTORY (2767-472X), 2(06), 82-85. 